\title{
Heat stability of milk supplemented with calcium chloride
}

\author{
N. On-Nom, A. S. Grandison, and M. J. Lewis ${ }^{1}$ \\ Department of Food and Nutritional Sciences, University of Reading, Whiteknights, PO Box 226, Reading RG6 6AP, United Kingdom
}

\begin{abstract}
Calcium chloride $(0-25 \mathrm{~m} M)$ was added to skim milk powder that was reconstituted to $9 \%$ total solids. Heat stability was evaluated between 60 and $120^{\circ} \mathrm{C}$ for different times by observing whether samples had coagulated, and by measuring the amount of sediment and residual protein in the centrifuged supernatant. Milk samples were also dialyzed during their respective heat treatments to recover the soluble phase at different temperatures to measure $\mathrm{pH}$ and ionic calcium. The transition conditions between good and poor heat stability were established for different calcium chloride concentrations and temperatures. As temperature increased, coagulation occurred at lower levels of added calcium chloride. The transition was quite distinct at higher temperatures but less so at lower temperatures; it was initiated by an increase in sediment formation before a firm coagulum was formed. Both $\mathrm{pH}$ and ionic calcium decreased in dialysates as temperature increased. No coagulation was observed if $\mathrm{Ca}^{2+}$ was $<0.5 \mathrm{mM}$ and $\mathrm{pH}$ was $>6.3$ in dialysates taken at their respective coagulation temperatures. Being able to measure $\mathrm{pH}$ and ionic calcium at high temperatures will allow better understanding of factors affecting heat stability. Electrophoresis of the supernatants permitted identification of the protein fractions participating in the coagulation process. When coagulation was observed below $80^{\circ} \mathrm{C}$, substantial amounts of undenatured $\beta$-lactoglobulin and $\alpha$-lactalbumin were found in the supernatant, as well as some soluble casein fractions. All the major whey protein and casein fractions were found in the sediment.
\end{abstract}

Key words: $\mathrm{pH}$, ionic calcium, heat stability

\section{INTRODUCTION}

Calcium fortification of milk is challenging because its soluble phase is saturated with calcium at its normal $\mathrm{pH}$, making further addition difficult. Addition of

\footnotetext{
Received July 7, 2011.

Accepted December 11, 2011.

${ }^{1}$ Corresponding author: m.j.lewis@reading.ac.uk
}

$\mathrm{CaCl}_{2}$ has been found to decrease $\mathrm{pH}$ and increase ionic calcium $\left(\mathrm{Ca}^{2+}\right.$; Philippe et al., 2003; Tsioulpas et al., 2010). Philippe et al. (2003) reported that addition of $4.5 \mathrm{mM} \mathrm{CaCl}{ }_{2}$ increased $\mathrm{Ca}^{2+}$ in skim milk from 1.56 to $2.86 \mathrm{~m} M$; on $\mathrm{pH}$ readjustment, this was reduced to $2.67 \mathrm{mM} \mathrm{CaCl}_{2}$. About $80 \%$ of the added calcium was associated with the micelle and the addition of calcium was accompanied by an increase in inorganic phosphate and citrate in the micelle. Other changes observed were a decrease in soluble casein, an increase in milk protein hydrophobicity, and a decrease in casein micelle size without any change in hydrodynamic diameter.

The sensitivity of casein to calcium ions was studied by Pyne (1958) following $\mathrm{CaCl}_{2}$ addition to casein that had been resuspended. It was found that $18 \mathrm{mM} \mathrm{CaCl} 2$ was required to coagulate milk that had not been previously heat treated at $100^{\circ} \mathrm{C}$ for $3 \mathrm{~min}$, whereas $10 \mathrm{mM}$ $\mathrm{CaCl}_{2}$ was required for milk that had been preheated at $120^{\circ} \mathrm{C}$ for $2 \mathrm{~min}$. Longer preheating required greater than $10 \mathrm{~m} M$ calcium addition to promote coagulation. Sievanen et al. (2008) added up to $10 \mathrm{mM} \mathrm{CaCl}{ }_{2}$ to milk and to concentrated milk, which increased $\mathrm{Ca}^{2+}$ by 2.85 and $2.21 \mathrm{~m} M$, respectively, as well as reducing heat coagulation times. The heat coagulation time $/ \mathrm{pH}$ profile was shifted in a more alkaline direction. Grandison (1988) showed that adding $2.5 \mathrm{mM}$ of $\mathrm{CaCl}_{2}$ and $4.1 \mathrm{~m} M$ of magnesium chloride both gave substantial reductions in the run-time of a UHT plant. However, he did not report any $\mathrm{pH}$ changes accompanying these additions. Lewis et al. (2011) found a linear relationship between $\mathrm{pH}$ and $\log \mathrm{Ca}^{2+}$, and between ethanol stability and $\mathrm{Ca}^{2+}$. In some instances, only $2.7 \mathrm{mM}$ $\mathrm{CaCl}_{2}$ was required to cause voluminous sediment on UHT treatment. For higher calcium additions, it was necessary to reduce $\mathrm{Ca}^{2+}$ to prevent sediment formation. This could be achieved by addition of sodium hydroxide, or more effectively, by addition of stabilizers such as sodium hexametaphosphate, trisodium citrate, or disodium hydrogen phosphate. At the highest $\mathrm{CaCl}_{2}$ addition evaluated, it was determined that $\mathrm{Ca}^{2+}$, rather than $\mathrm{pH}$, was the predominant factor controlling sediment formation.

Tsioulpas et al. (2010) added $\mathrm{CaCl}_{2}$ to skim milk, which was then subjected to in-container sterilization. Only $4.5 \mathrm{~m} M$ was required to cause coagulation to 
occur on sterilization. Additions of calcium gluconate (CG) and calcium lactate (CL) have been less studied than $\mathrm{CaCl}_{2}$, but have been shown to have similar effects, although larger additions can be tolerated before milk becomes unstable to heat. Philippe et al. (2004) reported that addition of up to $16 \mathrm{mMCG}, \mathrm{CaCl}_{2}$, and CL had the same effect, decreasing diffusible anions (inorganic phosphate and citrate), increasing incorporation of casein molecules into the micelle, decreasing tightly bound water, changing casein micelle size, and decreasing heat stability.

Singh et al. (2007) studied calcium fortification of milk up to $50 \mathrm{mg} / 100 \mathrm{~mL}$ with $\mathrm{CaCl}_{2}$, CL, and CG. Restoration of $\mathrm{pH}$ with disodium hydrogen phosphate restored heat stability measured by heat coagulation time. Omoaruhke et al. (2010) compared addition of 6 calcium salts on heat stability to UHT and in-container sterilization and studied the differences between CG and CL in more detail.

Mineral partitioning at high temperature has been studied by Pouliot et al. (1989a,b,c). They found that soluble calcium decreased with increasing temperature up to $90^{\circ} \mathrm{C}$. It has been known for some time that milk $\mathrm{pH}$ decreases as temperature increases, and recently it has been reported that $\mathrm{Ca}^{2+}$ decreases as temperature increases (Walstra and Jenness, 1984; Ma and Barbano, 2003; Chandrapala et al., 2010). Although pH and $\mathrm{Ca}^{2+}$ are considered to be 2 important determinants of heat stability, they have rarely been measured at the temperatures at which heat stability was evaluated. Chandrapala et al. (2010) measured $\mathrm{pH}$ up to $80^{\circ} \mathrm{C}$ and $\mathrm{Ca}^{2+}$ up to $60^{\circ} \mathrm{C}$ directly, whereas On-Nom et al. (2010) measured $\mathrm{pH}$ and $\mathrm{Ca}^{2+}$ in dialysates and UF permeates at high temperatures. Both groups of researchers have shown that $\mathrm{pH}$ and $\mathrm{Ca}^{2+}$ decrease as temperature increases. However, these changes are reversible in milk. In dialysates recovered at high temperature, the latter researchers found that heat coagulation at $110^{\circ} \mathrm{C}$ occurred with addition of $5.4 \mathrm{mM} \mathrm{CaCl}$, when $\mathrm{pH}$ and $\mathrm{Ca}^{2+}$ of the dialysate were 6.00 and $0.43 \mathrm{mM}$, respectively. Corresponding values in milk at $20^{\circ} \mathrm{C}$ were $\mathrm{pH} 6.66$ and $\mathrm{Ca}^{2+}$ of $2.10 \mathrm{mM}$.

McKinnon et al. (2009) added up to $10 \mathrm{mM} \mathrm{CaCl}_{2}$ and measured $\mathrm{pH}$ in situ during heating. They concluded that $\mathrm{pH}$ at the heating temperature is a more important parameter than the initial $\mathrm{pH}$ in influencing heat-induced changes in milk. Addition of calcium results in a larger decrease in $\mathrm{pH}$ during heating and is responsible for the reduction in heat stability of milks with added calcium.

The aim of this paper was to examine the role of $\mathrm{pH}$ and $\mathrm{Ca}^{2+}$ on heat stability of reconstituted skim milk subjected to different $\mathrm{CaCl}_{2}$ additions. These param- eters were measured both at ambient temperature and at different temperatures between 60 and $120^{\circ} \mathrm{C}$.

\section{MATERIALS AND METHODS}

Skim milk powder was reconstituted to $9 \%$ total solids using distilled water. The undenatured whey protein content was approximately $65 \%$. First, different concentrations of $\mathrm{CaCl}_{2}$ were added to reconstituted skim milk, which was then sterilized in cans at $115^{\circ} \mathrm{C}$ for 30 min. Samples were also dialyzed during the sterilization procedure by placing dialysis bags in the cans. The aim of this procedure was to isolate the soluble phase of milk at different temperatures as a procedure for determining the $\mathrm{pH}$ and ionic calcium values at those temperatures. Dialysis bags were removed immediately after heat treatment and $24 \mathrm{~h}$ after heat treatment. The heated samples were centrifuged and evaluated for sediment and soluble protein. This was replicated 3 times.

Second, the effects of heating temperatures in the range from 60 to $120^{\circ} \mathrm{C}$ for $1 \mathrm{~h}$ were studied. At each temperature, a range of $\mathrm{CaCl}_{2}$ concentrations was selected to observe thresholds for coagulation in terms of sediment formation and visible coagulation. Dialysis was also performed under these different heating conditions. The experimental range of 60 to $80^{\circ} \mathrm{C}$ (the area in which whey protein denaturation will occur) was studied in more detail.

\section{Dialysis}

The dialysis tubing used was Visking tubing, size 9, with an internal diameter of $28.6 \mathrm{~mm}$ and a molecular weight cut-off of $12 \mathrm{kDa}$ (Medicell International Ltd., London, UK). The dialysis procedure is described by On-Nom et al. (2010). The milk to water ratio was 12:1. For dialysis at $20^{\circ} \mathrm{C}$, the period was $24 \mathrm{~h}$, and $0.05 \%$ sodium azide was added to the milk to prevent microbial activity. For dialysis at $60^{\circ} \mathrm{C}$ and above, dialysis bags were removed as quickly as possible after the end of the heating period.

\section{Analytical Methods}

Measurements were taken on permeates and dialysates that had been kept overnight before measurement, except where otherwise stated. The $\mathrm{pH}$ of milk, dialysis, and permeate samples was measured by using an $\mathrm{HI}$ 8424 Digital pH meter (Hanna Instruments, Leighton Buzzard, UK). The $\mathrm{pH}$ probe was calibrated using standards of $\mathrm{pH} 4$ and 7 (VWR International Ltd., Poole, UK) at $20^{\circ} \mathrm{C}$. Ionic calcium was measured using a Ciba Corning 634 Analyzer (Bayer plc, Newbury, 
UK), described by Lin et al. (2006). The instrument was calibrated daily with $5 \mathrm{Ca}^{2+}$ standards, selected from the range 0.25 to $3.0 \mathrm{mM}$.

\section{Centrifugation and Sediment Measurement}

Sediment formation was measured by centrifuging the sample at $2,760 \times g$ and determining the dry weight of the sediment (Boumpa et al., 2008). The supernatant was carefully removed from sediment and stored at $-20^{\circ} \mathrm{C}$ for future analysis. Sediment was kept at $-20^{\circ} \mathrm{C}$ overnight before freezing dry. These sediment and supernatant samples were used in reducing SDS (RSDS)-PAGE.

\section{RSDS-PAGE}

The freeze-dried sediment was crushed to a fine powder. Then, $0.03 \mathrm{~g}$ of sediment power was dissolved in 5 $\mathrm{mL}$ of deionized water and mixed well for 20 min with a magnetic stirrer. The frozen supernatant was thawed at room temperature. A modified method of Laemmli (1970) was used for RSDS-PAGE. The sample buffer contained $0.0625 M$ Tris-HCl (pH 6.8), $2 \%$ SDS, $25 \%$ glycerol, $5 \%$ 2-mercaptoethanol, and $0.001 \%$ bromophenol blue as dye. Dissolved sediment and supernatant were mixed with the sample buffer in the ratio 100 $\mu \mathrm{L}: 150 \mu \mathrm{L}$ and heated in boiling water for $3 \mathrm{~min}$. Twenty microliters of sample was loaded per lane. The stacking gel of $4 \%$ acrylamide consisted of $0.125 M$ Tris- $\mathrm{HCl}(\mathrm{pH}$ 6.8), $0.1 \%$ SDS, $0.1 \% N, N, N^{\prime}, N^{\prime}$-tetramethylenediamine (TEMED), and $0.05 \%$ ammonium persulfate solution. The separating gel ( $12 \%$ acrylamide) consisted of 0.375 $M$ Tri-HCl (pH 8.8), 0.1\% SDS, $0.04 \%$ TEMED, and $0.1 \%$ ammonium persulfate solution. The stock electrode buffer $\left(4^{\circ} \mathrm{C}\right)$ contained $0.025 M$ Tris, $0.192 M$ glycine, and $0.1 \%$ SDS. It was diluted 5 times before use. The power to the mini-Protean II cell was supplied by an external DC voltage power supply (Power Pac 3000, Bio-Rad, Hercules, CA) at $112 \mathrm{~V}$ for $20 \mathrm{~min}$ and at $224 \mathrm{~V}$ for $40 \mathrm{~min}$. The gels were stained overnight in Coomassie Blue G250 (0.1\%, wt/vol) in methanol:acetic acid:water $(4: 1: 5, \mathrm{vol} / \mathrm{vol} / \mathrm{vol})$ and destained in the same solution without dye.

\section{Protein Analysis}

The advanced protein assay reagent (Sigma Chemicals, St. Louis, MO) was used to determine the protein concentration. The protein standard (BSA) was prepared as standard solutions of $0,1,2,3,4$, and 5 $\mathrm{mg} / \mathrm{mL}$. Then, $10 \mu \mathrm{L}$ of standard solution and sample solution (supernatants and dissolved sediment) were mixed with $1 \mathrm{~mL}$ of protein assay reagent. The colors of solutions changed from green to blue. The absorbance of the resulting blue color was determined against a blank solution at $600 \mathrm{~nm}$.

\section{Statistical Analysis}

For experiments that were replicated 3 times, SPSS software (version 16, SPSS Inc., Chicago, IL) was used to analyze for significant differences between calcium concentrations and between different treatments.

\section{RESULTS}

Results for $\mathrm{pH}$ and $\mathrm{Ca}^{2+}$ before and after sterilization at $115^{\circ} \mathrm{C}$ for $30 \mathrm{~min}$ are shown in Table 1 . Addition of $\mathrm{CaCl}_{2}$ reduced $\mathrm{pH}$ and increased $\mathrm{Ca}^{2+}$. Milk containing $\geq 7.2 \mathrm{mM} \mathrm{CaCl}{ }_{2}$ coagulated on heating, whereas milk with $\leq 3.6 \mathrm{mM} \mathrm{CaCl}$ did not coagulate. Sterilization reduced the $\mathrm{pH}$ of milk at all $\mathrm{CaCl}_{2}$ concentrations. However, changes were not statistically significant. Sterilization also reduced $\mathrm{Ca}^{2+}$, and in the 2 instances where coagulation was not observed, $\mathrm{Ca}^{2+}$ were not significantly lower $(P>0.05)$ after heat treatment.

Analytical results for dialysates from milk at $20^{\circ} \mathrm{C}$ and from sterilized milk samples are shown in Table 2. The $\mathrm{Ca}^{2+}$ values of dialysates from milk samples at

Table 1. Analysis of $9 \%$ skim milk powder with addition of $\mathrm{CaCl}_{2}\left(20^{\circ} \mathrm{C}\right.$ for $24 \mathrm{~h}$ and $115^{\circ} \mathrm{C}$ for $\left.30 \mathrm{~min}\right)$, based on 3 replicated trials

\begin{tabular}{lccccc}
\hline & \multicolumn{2}{c}{ Original milk } & & \multicolumn{2}{c}{ Heated milk $\left(115^{\circ} \mathrm{C}, 30 \mathrm{~min}\right)$} \\
\cline { 2 - 3 } \cline { 5 - 6 } $\begin{array}{l}\text { Added } \\
\mathrm{CaCl}_{2}(\mathrm{~m} M)\end{array}$ & $\mathrm{pH}$ & $\mathrm{Ca}^{2+}(\mathrm{m} M)$ & & $\mathrm{pH}$ & $\mathrm{Ca}^{2+}(\mathrm{m} M)$ \\
\hline 0 & $6.83 \pm 0.04^{\mathrm{a}}$ & $1.32 \pm 0.16^{\mathrm{a}}$ & & $6.64 \pm 0.04^{\mathrm{a}}$ & $1.23 \pm 0.20$ \\
3.6 & $6.72 \pm 0.03^{\mathrm{b}}$ & $1.88 \pm 0.24^{\mathrm{a}}$ & & $6.53 \pm 0.05^{\mathrm{b}}$ & $1.87 \pm 0.29$ \\
7.2 & $6.61 \pm 0.04^{\mathrm{c}}$ & $2.98 \pm 0.31^{\mathrm{b}}$ & & $6.43 \pm 0.03^{\mathrm{c}}$ & $\mathrm{NA}^{1}$ \\
10.8 & $6.49 \pm 0.02^{\mathrm{d}}$ & $4.16 \pm 0.49^{\mathrm{c}}$ & & $6.37 \pm 0.04^{\mathrm{c}}$ & $\mathrm{NA}^{\mathrm{d}}$ \\
14.4 & $6.40 \pm 0.03^{\mathrm{e}}$ & $5.62 \pm 0.82^{\mathrm{d}}$ & & $6.27 \pm 0.04^{\mathrm{d}}$ & $\mathrm{NA}$ \\
18.0 & $6.32 \pm 0.04^{\mathrm{f}}$ & $7.39 \pm 1.00^{\mathrm{e}}$ & & $6.23 \pm 0.05^{\mathrm{d}}$ & $\mathrm{NA}$ \\
\hline
\end{tabular}

${ }^{\mathrm{a}-\mathrm{f}}$ Values (mean $\left.\pm \mathrm{SD}\right)$ in the same column followed by the same letter are not significantly different $(P>0.05)$. ${ }^{1} \mathrm{NA}=$ not available (sample coagulated). 
Table 2. Analysis of dialysates of $9 \%$ skim milk powder with added $\mathrm{CaCl}_{2}$ after heating at $115^{\circ} \mathrm{C}$ for 30 min, after heating at $115^{\circ} \mathrm{C}$ for 30 min followed by storage at $20^{\circ} \mathrm{C}$ for $24 \mathrm{~h}$, and after dialysis of unheated milk at $20^{\circ} \mathrm{C}$ for $24 \mathrm{~h}$ (based on 3 replicated trials)

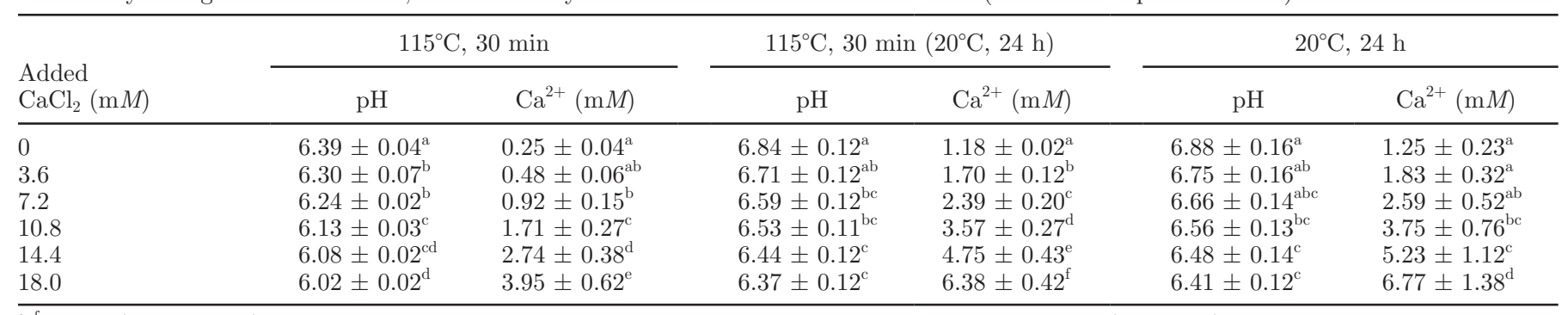

${ }^{\mathrm{a}-\mathrm{f}}$ Values $(\mathrm{mean} \pm \mathrm{SD})$ in the same column followed by the same letter are not significantly different $(P>0.05)$.

$20^{\circ} \mathrm{C}$ were similar to those in the corresponding milk samples. The $\mathrm{pH}$ of dialysates was consistently higher than in their corresponding milk samples. In contrast, dialysates obtained at $115^{\circ} \mathrm{C}$ and removed quickly had much lower $\mathrm{pH}$ and $\mathrm{Ca}^{2+}$ values compared with the original milk. This is in line with previous observations (On-Nom et al., 2010).

However, when dialysis bags were left in the heated sample for $24 \mathrm{~h}$, the $\mathrm{pH}$ and $\mathrm{Ca}^{2+}$ values of dialysates returned to close to their original values. In most cases, the $\mathrm{pH}$ and $\mathrm{Ca}^{2+}$ of these dialysates (removed after 24 $\mathrm{h}$ ) and unheated milk dialyzed for $24 \mathrm{~h}$ were not significantly different. However, the fact that dialysates removed at high temperature but measured at room temperature had a much lower $\mathrm{pH}$ and $\mathrm{Ca}^{2+}$ compared with cooled heated milk demonstrates that significant changes in these properties occurred when milk cooled compared with when the dialysate cooled. Throughout this work, data resulting from dialysis at different temperatures are interpreted as providing a novel indirect method for measuring the $\mathrm{Ca}^{2+}$ and $\mathrm{pH}$ of milk at those temperatures.

Accordingly, when milk temperature increases, its $\mathrm{pH}$ and $\mathrm{Ca}^{2+}$ both decrease. On cooling, this is reversible as shown both in milk samples and in dialysates that were left in heated milk samples for $24 \mathrm{~h}$. Thus, this dialysis procedure also provides a means of demonstrating the reversibility of $\mathrm{pH}$ and other changes when milk is heated and cooled. This is also useful for measuring the soluble phase of a coagulated sample. Note that the threshold conditions for the onset of coagulation (i.e., on addition of $7.2 \mathrm{mM} \mathrm{CaCl} 2$ ) measured at $115^{\circ} \mathrm{C}$ by dialysis were between 6.24 and 6.30 for $\mathrm{pH}$ and between 0.48 and $0.92 \mathrm{mM}$ for $\mathrm{Ca}^{2+}$ (Table 2).

Protein levels in the centrifuged supernatants decreased dramatically between 3.6 and $7.2 \mathrm{mM} \mathrm{CaCl} 2$ addition, from $31.6 \mathrm{mg} / \mathrm{mL}$ to $1.80 \mathrm{mg} / \mathrm{mL}$. In fact, virtually all the protein had coagulated at $7.2 \mathrm{~m} M$ addition. We also observed that coagulation was associated with large amounts of sediment, in addition to a muchreduced amount of soluble protein in the supernatant.
Analyses showed that between 50 and $60 \%$ of the dry weight of the sediment was protein (results not shown).

These findings were further confirmed by electrophoresis, where a clear reduction in soluble protein was observed between 3.6 and $7.2 \mathrm{mM}$ (Figure 1). Some residual undenatured whey protein was observed in supernatant following this sterilization procedure, which appeared to decrease with an increase in $\mathrm{CaCl}_{2}$ concentration and almost completely disappeared at the highest concentration of $\mathrm{CaCl}_{2}$. Some soluble $\kappa$ - and $\beta$-casein was also observed, although little $\alpha$-casein, which is in line with the calcium sensitivities of these different casein factions. It is noteworthy that differences between soluble $\kappa$-casein at different levels of calcium addition were small, which suggests that this was not a major factor in terms of causing poor heat stability. All casein and whey protein fractions were found in the sediment, although the amounts of $\beta-\mathrm{LG}$, $\alpha-\mathrm{LA}$, and casein fractions increased as $\mathrm{CaCl}_{2}$ addition increased.

\section{Heating Between $60^{\circ} \mathrm{C}$ and $120^{\circ} \mathrm{C}$ : Analysis of Milk Samples}

When milk with a range of $\mathrm{CaCl}_{2}$ concentrations was heated between 60 and $120^{\circ} \mathrm{C}$, it was found that milk samples started to coagulate at lower levels of calcium addition as the heating temperature increased (Table 3 ). The $\mathrm{pH}$ and $\mathrm{Ca}^{2+}$ conditions marking the onset of coagulation in the original milk samples are shown at each temperature in Table 3 . At $60^{\circ} \mathrm{C}$, both a low $\mathrm{pH}$ and a high $\mathrm{Ca}^{2+}$ concentration were required to initiate coagulation, whereas between $70^{\circ} \mathrm{C}$ and $100^{\circ} \mathrm{C}$, coagulation occurred at lower concentrations of $\mathrm{Ca}^{2+}$, although $\mathrm{pH}$ was within a fairly narrow range. At $120^{\circ} \mathrm{C}$, all milk samples coagulated.

The experiment was repeated using a narrower range of $\mathrm{CaCl}_{2}$ concentrations selected so that, at each experimental temperature, some samples would be heat stable and some would not. The threshold concentrations between good and poor heat stability at different heating 
Table 3. $\mathrm{pH}$ and $\mathrm{Ca}^{2+}$ values for the highest concentration of added $\mathrm{CaCl}_{2}$ that did not cause coagulation ${ }^{1}$

\begin{tabular}{|c|c|c|c|c|c|}
\hline \multirow{2}{*}{$\begin{array}{l}\text { Temperature } \\
\left({ }^{\circ} \mathrm{C}\right)\end{array}$} & \multirow{2}{*}{$\begin{array}{l}\text { Added } \mathrm{CaCl}_{2} \\
\quad(\mathrm{~m} M)\end{array}$} & \multicolumn{2}{|c|}{$\begin{array}{l}\text { Skim milk properties just } \\
\text { before coagulation }\end{array}$} & \multicolumn{2}{|c|}{ Dialysates } \\
\hline & & $\mathrm{pH}$ & $\mathrm{Ca}^{2+}(\mathrm{m} M)$ & $\mathrm{pH}$ & $\mathrm{Ca}^{2+}(\mathrm{m} M)$ \\
\hline 70 & $10.8(14.4)$ & 6.45 & 3.65 & $6.15(6.04)$ & $2.64(3.86)$ \\
\hline 80 & $7.2(10.8)$ & 6.55 & 2.49 & $6.17(6.07)$ & $1.56(2.37)$ \\
\hline 90 & $7.2(10.8)$ & 6.52 & 2.60 & $6.24(6.19)$ & $1.47(2.06)$ \\
\hline
\end{tabular}

${ }^{1}$ Values in parentheses are the first set of conditions that caused coagulation.

${ }^{2} \mathrm{At} 120^{\circ} \mathrm{C}$, all samples coagulated.

temperatures were assessed by several procedures and the results are summarized in Table 4 .

The concentration range for the onset of formation of a firm coagulum is in broad agreement with earlier results and all samples coagulated at $120^{\circ} \mathrm{C}$. Considered as a method for obtaining a firm milk protein coagulum, high protein recovery was obtained at $90^{\circ} \mathrm{C}$ using addition of $9 \mathrm{mM} \mathrm{CaCl}$.

As well as observing whether coagulation had occurred, we also measured the amount of sediment. In the lower temperature range a substantial amount of sediment was detected before coagulation was observed (data not presented). It was found that sediment increased with increasing $\mathrm{CaCl}_{2}$ addition and increasing temperature. With addition of $\geq 10 \mathrm{mM} \mathrm{CaCl}_{2}$, excessive sediment was observed at temperatures of $80^{\circ} \mathrm{C}$ and above. Similar trends were found when residual protein in the supernatant was measured. A good correlation was found between sediment and protein concentration in the supernatant (Figure 2): between $60^{\circ} \mathrm{C}$ and $110^{\circ} \mathrm{C}$, $\mathrm{R}^{2}$ was $>0.95$, whereas at $120^{\circ} \mathrm{C}, \mathrm{R}^{2}$ was $<0.9$.

Electrophoresis was also performed on supernatants. Threshold conditions corresponding to removal of most of the casein fraction are shown in Figure 3 and are summarized in Table 4 . At $60^{\circ} \mathrm{C}$, the range was wide, between 19.8 and $23.4 \mathrm{mM}$. Electrophoresis results for supernatants showed that considerable undenatured whey protein was present in the supernatant at $60^{\circ} \mathrm{C}$ and $70^{\circ} \mathrm{C}$. This is interesting and shows that whey protein denaturation is not a prerequisite for heat-induced destabilization. From $80^{\circ} \mathrm{C}$ onward, content of $\beta-\mathrm{LG}$ and $\alpha$-LA started to decrease. We observed that $\beta$-LG denaturation increased as $\mathrm{CaCl}_{2}$ addition increased and that denaturation increased significantly when coagulation occurred. Undenatured whey protein could still be detected at $110^{\circ} \mathrm{C}$, and small amounts of soluble caseins were present in the supernatants, but these were minimal at $90^{\circ} \mathrm{C}$.

Results for electrophoresis of freeze-dried sediment are shown in Figure 3. The procedure for measuring sediment provided some interesting results. Even at temperatures of $60^{\circ} \mathrm{C}$, substantial whey protein was present in the sediments. The intensity of the bands for sediment became less intense as temperature increased, perhaps because sediment was more complex and less easily broken down. Overall, the sediment produced at $120^{\circ} \mathrm{C}$ was very different in its solubility characteristics compared with that produced at lower temperatures.

\section{Dialysis Results}

$\mathrm{pH}$ and $\mathrm{Ca}^{2+}$ were measured for dialysates obtained at each of the heating conditions. The data for a range of temperatures are presented in Figure 4. The main conclusion from the dialysis experiments was that $\mathrm{pH}$ and $\mathrm{Ca}^{2+}$ in dialysates decreased as dialysis tempera-

Table 4. Conditions for onset of poor heat stability in skim milk powder with different concentrations of $\mathrm{CaCl}_{2}(\mathrm{range}$; $\mathrm{m} M)$ added as determined by different procedures (electrophoresis, sediment, protein in sediment, protein in supernatant)

\begin{tabular}{|c|c|c|c|c|}
\hline $\begin{array}{l}\text { Temperature } \\
\left({ }^{\circ} \mathrm{C}\right)\end{array}$ & Electrophoresis & Sediment & $\begin{array}{c}\text { Protein } \\
\text { in sediment }\end{array}$ & $\begin{array}{l}\text { Protein in } \\
\text { supernatant }\end{array}$ \\
\hline 60 & 19.8 to 23.4 & 16.2 to 18.0 & 18.0 to 19.8 & 16.2 to 18 \\
\hline 70 & 10.8 to 12.6 & $<10.8$ & 10.8 to 12.6 & 10.8 to 12.6 \\
\hline 90 & 7.2 to 9.0 & $<7.2$ & $<7.2$ & $<9.0$ \\
\hline 100 & 5.4 to 7.2 & 3.6 to 7.2 & 5.4 to 7.2 & 5.4 to 7.2 \\
\hline 110 & 5.4 to 7.2 & 3.6 to 5.4 & 5.4 to 7.2 & 3.6 to 7.2 \\
\hline
\end{tabular}


$\begin{array}{lllllllllllll}1 & 2 & 3 & 4 & 5 & 6 & 7 & 8 & 9 & 10 & 11 & 12\end{array}$

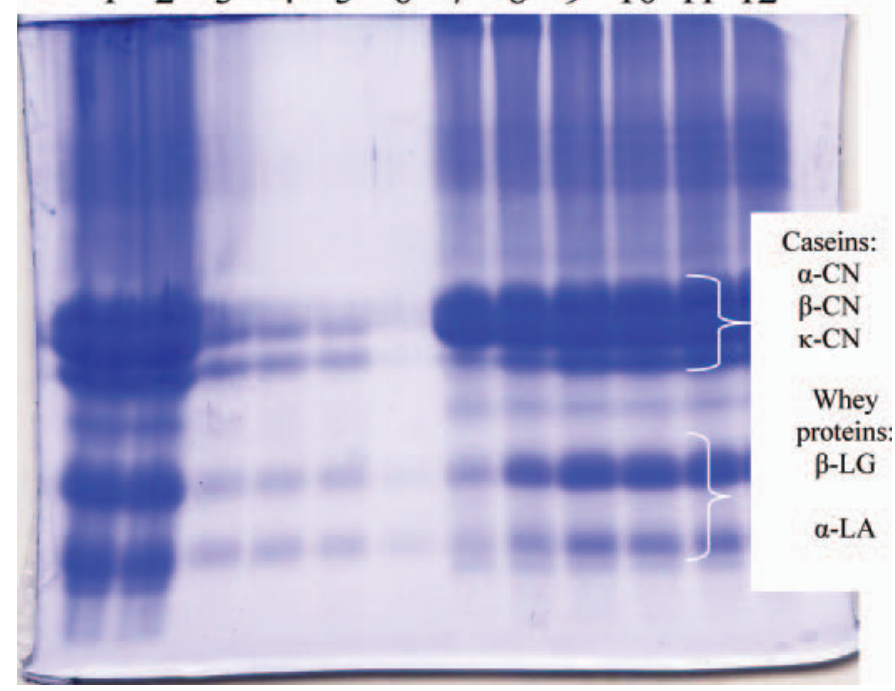

Figure 1. Sodium dodecyl sulfate-PAGE of supernatant (lanes 1 to 6) and sediment (lanes 7 to 12 ) obtained from $9 \%$ skim milk powder $(\mathrm{SMP})$ with calcium chloride addition at $115^{\circ} \mathrm{C}$ for $30 \mathrm{~min}$. Lane $1=$ $\mathrm{SMP}+0 \mathrm{mMCaCl}$; lane $2=\mathrm{SMP}+3.6 \mathrm{mM} \mathrm{CaCl}_{2}$; lane $3=\mathrm{SMP}$ $+7.2 \mathrm{mM} \mathrm{CaCl}_{2}$; lane $4=\mathrm{SMP}+10.8 \mathrm{mM} \mathrm{CaCl}$; lane $5=\mathrm{SMP}+$ $14.4 \mathrm{mM} \mathrm{CaCl}_{2}$; lane $6=\mathrm{SMP}+18.0 \mathrm{mM} \mathrm{CaCl}$; lane $7=\mathrm{SMP}+0$ $\mathrm{m} M \mathrm{CaCl}_{2}$; lane $8=\mathrm{SMP}+3.6 \mathrm{~m} M \mathrm{CaCl}_{2} ;$ lane $9=\mathrm{SMP}+7.2 \mathrm{mM}$ $\mathrm{CaCl}_{2} ;$ lane $10=\mathrm{SMP}+10.8 \mathrm{mM} \mathrm{CaCl} \mathrm{Cl}_{2} ;$ lane $11=\mathrm{SMP}+14.4 \mathrm{mM}$ $\mathrm{CaCl}_{2}$; lane $12=\mathrm{SMP}+18.0 \mathrm{mM} \mathrm{CaCl}$. Color version available in the online PDF.

ture increased. Adding $\mathrm{CaCl}_{2}$ to milk increased $\mathrm{Ca}^{2+}$ and decreased $\mathrm{pH}$ of milk and their respective dialysates collected at high temperature.

When data were plotted at different temperatures, the gradient of the relationship between $\log \mathrm{Ca}^{2+}$ and $\mathrm{pH}$ was constant. Thus, both $\mathrm{pH}$ and $\mathrm{Ca}^{2+}$ decreased as heating temperature was increased. Figure 4 represents these data and shows which samples coagulated and which did not. At $80^{\circ} \mathrm{C}$ and above, no coagulation occurred, provided that $\mathrm{pH}$ did not fall below 6.30 and $\mathrm{Ca}^{2+}$ was below $0.46 \mathrm{mM}$. However, at $60^{\circ} \mathrm{C}$, much lower $\mathrm{pH}$ and higher $\mathrm{Ca}^{2+}$ concentrations were required to induce coagulation. Again, at the lower heating temperatures, considerable sediment was observed before visible coagulation took place.

\section{Heat Stability Between $60^{\circ} \mathrm{C}$ and $80^{\circ} \mathrm{C}$}

Further heat stability trials were done between 60 and $80^{\circ} \mathrm{C}$. In this temperature range, we observed that coagulation was preceded by some sediment formation. At $60^{\circ} \mathrm{C}$, no coagulation was observed (up to $20 \mathrm{mM}$ addition), but sediment formation became noticeable. It was interesting that coagulation did take place at $65^{\circ} \mathrm{C}$ and $70^{\circ} \mathrm{C}$ under conditions where whey protein denaturation was minimal, suggesting that the dena- turation of whey protein is not an essential process for heat-induced aggregation of casein micelles.

Sediment formation was plotted against $\mathrm{pH}$ and $\mathrm{Ca}^{2+}$ of dialysates taken between 60 and $80^{\circ} \mathrm{C}$ (Figures 5 and 6). No significant sediment formed if $\mathrm{pH}$ was maintained above 6.3 and $\mathrm{Ca}^{2+}$ was below $2.0 \mathrm{mM}$. The combined role of $\mathrm{pH}$ and $\mathrm{Ca}^{2+}$ in heat stability is shown in Figure 7, where distinct regions of high heat stability and low heat stability were found.

\section{DISCUSSION}

Singh (2004) pointed out that correlations between different test methods are generally unsatisfactory and that heat coagulation time (heat stability) measured by these methods often correlates very poorly with the stability of milk on commercial sterilization. This paper aimed to simulate conditions encountered during incontainer processes. Heat instability was manifested in 2 ways as $\mathrm{CaCl}_{2}$ concentration increased. First, production of considerable sediment at lower $\mathrm{CaCl}_{2}$ additions, and second, coagulation at higher additions. This was more noticeable at lower temperatures. A milk sample showing some sediment might appear to be heat stable, but this sediment can be detected by centrifugation and probably by taste. This illustrates the complexity of the changes taking place, even with this relatively simple heating procedure. Electrophoresis has also shown that at lower temperatures $\left(60\right.$ to $\left.80^{\circ} \mathrm{C}\right)$, the transition between no casein being removed from the supernatant and most of the casein being removed from

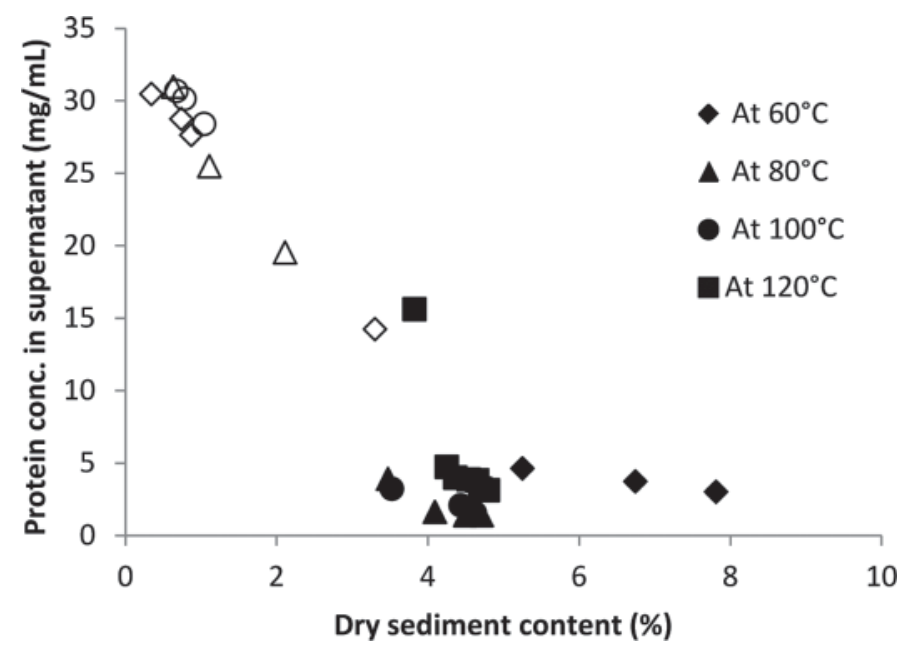

Figure 2. Dry sediment content (\%) against protein concentration of supernatant $(\mathrm{mg} / \mathrm{mL})$ of $9 \%$ skim milk powder (SMP) with added calcium chloride heated at $60^{\circ} \mathrm{C}$ (diamonds), $80^{\circ} \mathrm{C}$ (triangles), $100^{\circ} \mathrm{C}$ (circles), and $120^{\circ} \mathrm{C}$ (squares). Open symbols = no coagulation; solid symbols $=$ coagulation. 
a. At $60^{\circ} \mathrm{C}$

$\begin{array}{lllllllllllllll}0 & 14.4 & 16.2 & 18 & 19.8 & 21.6 & 23.4 & 0 & 14.4 & 16.2 & 18 & 19.8 & 21.6 & 23.4 & \begin{array}{c}\mathrm{CaCl}_{2} \text { added } \\ (\mathrm{mM})\end{array}\end{array}$

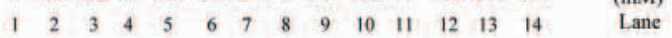

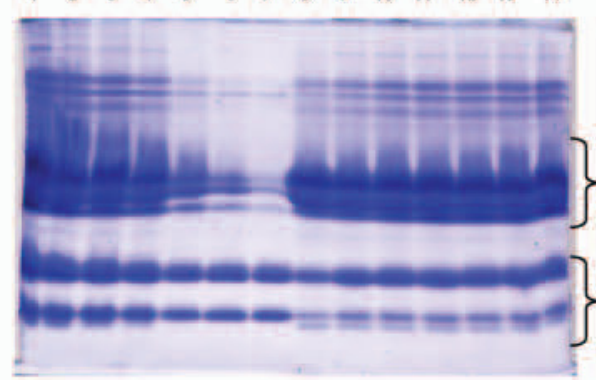

c. At $80^{\circ} \mathrm{C}$

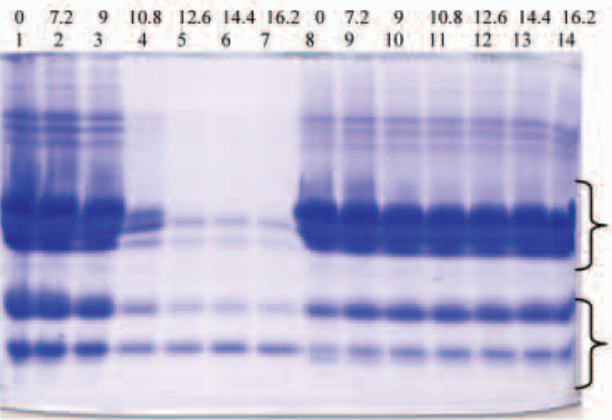

e. At $100^{\circ} \mathrm{C}$

$\begin{array}{llllllllllllll}0 & 3.6 & 5.4 & 7.2 & 9 & 10.8 & 12.6 & 0 & 3.6 & 5.4 & 7.2 & 9 & 10.8 & 12.6\end{array}$ $\begin{array}{llllllllllllll}1 & 2 & 3 & 4 & 5 & 6 & 7 & 8 & 9 & 10 & 11 & 12 & 13 & 14\end{array}$

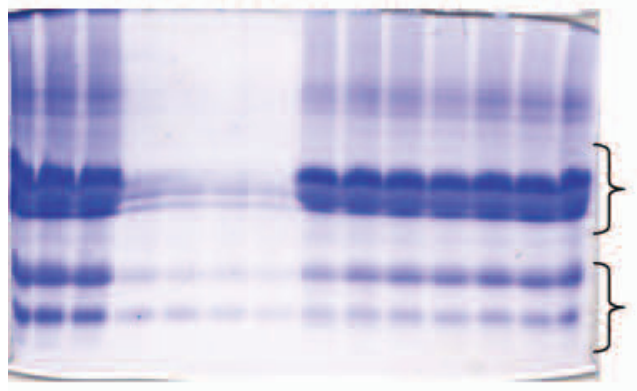

$\mathrm{CaCl}_{2}$ added

(mM)

Lane

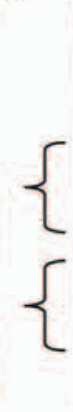

d. At $90^{\circ} \mathrm{C}$

b. At $70^{\circ} \mathrm{C}$

$\begin{array}{llllllllllllll}10.8 & 12.6 & 14.4 & 16.2 & 18 & 19.8 & 0 & 10.8 & 12.6 & 14.4 & 16.2 & 18 & 19.8\end{array}$

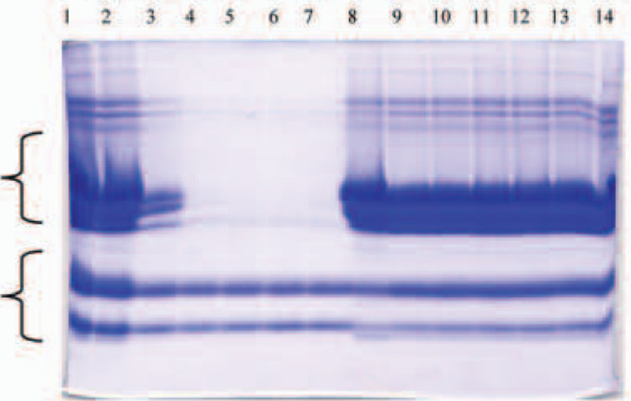

$\begin{array}{llllllllllllll}7.2 & 9 & 10.8 & 12.6 & 14.4 & 16.2 & 0 & 7.2 & 9 & 10.8 & 12.6 & 14.4 & 16.2\end{array}$

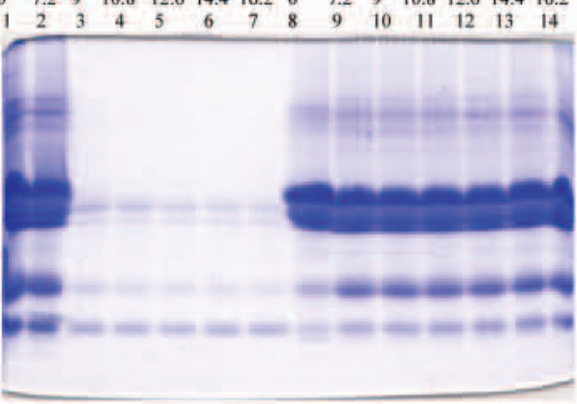

$\mathrm{CaCl}_{2}$ added f. At $110^{\circ} \mathrm{C}$

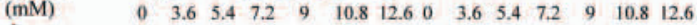

$\begin{array}{lllllllllllllll}\text { Lane } & \quad & 2 & 3 & 4 & 5 & 6 & 7 & 8 & 9 & 10 & 11 & 12 & 13 & 14\end{array}$

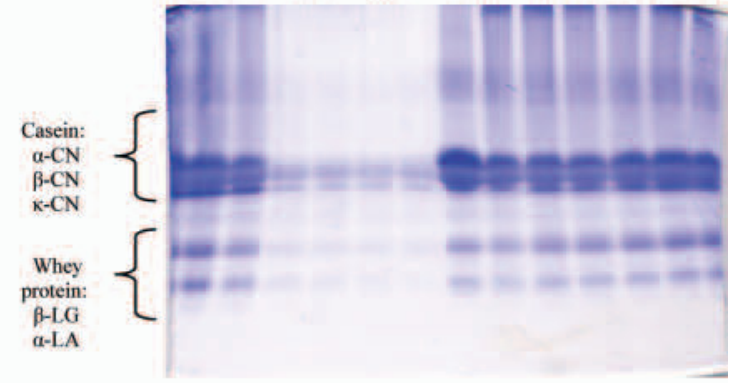

g. At $120^{\circ} \mathrm{C}$

$\begin{array}{lllllllllllllll}0 & 3.6 & 5.4 & 7.2 & 9 & 10.8 & 12.6 & 0 & 3.6 & 5.4 & 7.2 & 9 & 10.8 & 12.6\end{array}$

$\begin{array}{llllllllllllll}1 & 2 & 3 & 4 & 5 & 6 & 7 & 8 & 9 & 10 & 11 & 12 & 13 & 14\end{array}$

$$
\begin{gathered}
\mathrm{CaCl}_{2} \text { added } \\
\text { (mM) } \\
\text { Lane }
\end{gathered}
$$

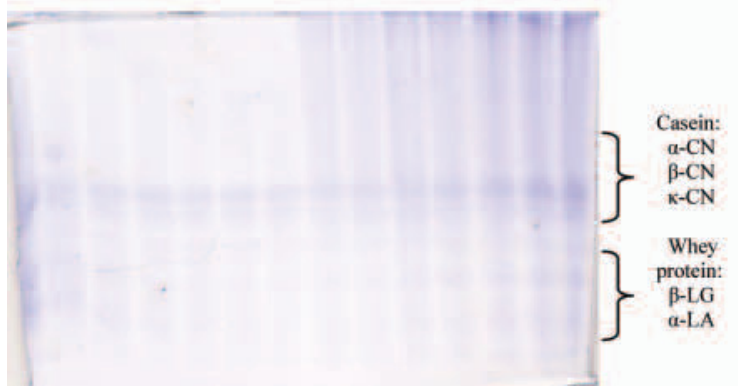

Figure 3. Sodium dodecyl sulfate-PAGE of supernatant (lanes 1 to 7 ) and sediment (lanes 8 to 14 ) obtained from $9 \%$ skim milk powder (SMP) with added calcium chloride at 60 to $120^{\circ} \mathrm{C}$ for $1 \mathrm{~h}$. Color version available in the online PDF 


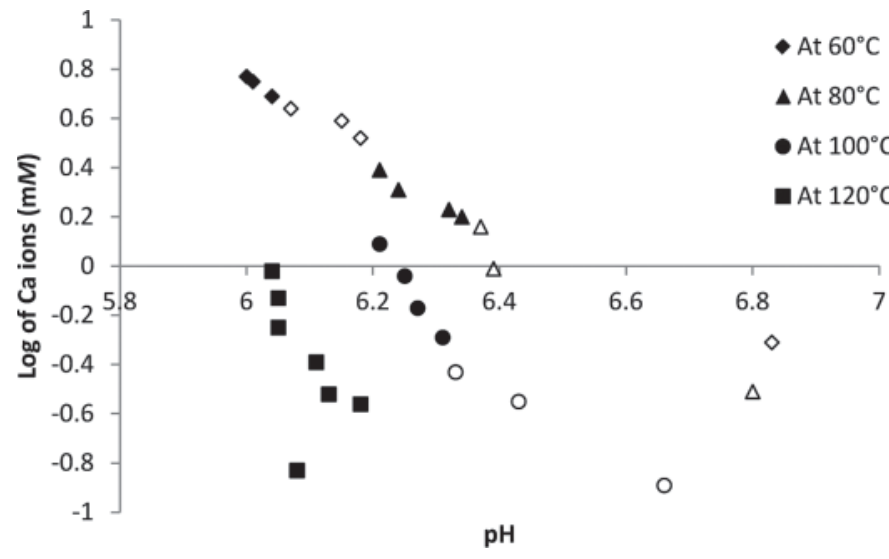

Figure 4. $\mathrm{pH}$ against log of calcium ion concentration of dialysates of $9 \%$ skim milk powder (SMP) at $60^{\circ} \mathrm{C}$ (diamonds), $80^{\circ} \mathrm{C}$ (triangles), $100^{\circ} \mathrm{C}$ (circles), and $120^{\circ} \mathrm{C}$ (squares) in calcium chloride supplemented milk. Open symbols $=$ no coagulation; solid symbols $=$ coagulation .

the supernatant occurs over a much wider concentration range than is observed at $90^{\circ} \mathrm{C}$ and above.

Both the $\mathrm{pH}$ and $\mathrm{Ca}^{2+}$ of dialysates obtained and removed at high temperature decreased as temperature increased. In contrast, both the $\mathrm{pH}$ and $\mathrm{Ca}^{2+}$ of the heated milk after cooling and for dialysate left in the can for $24 \mathrm{~h}$ reverted toward their original values. We found consistently that dialysates removed at high temperature did not demonstrate this degree of reversibility and their $\mathrm{pH}$ and $\mathrm{Ca}^{2+}$ changed little on cooling from the heating temperature to the ambient temperature. We propose that this occurs because soluble calcium and phosphorus are much decreased, so that no solubilization of calcium phosphate will occur as the dialysate cools. In contrast, dialysates removed at $20^{\circ} \mathrm{C}$ have been shown to exhibit considerable temperature dependence for these properties. This has been studied and described in more detail by Kaombe et al. (2012).

On-Nom et al. (2010) propose that dialysis at high temperature provides a procedure for determining how

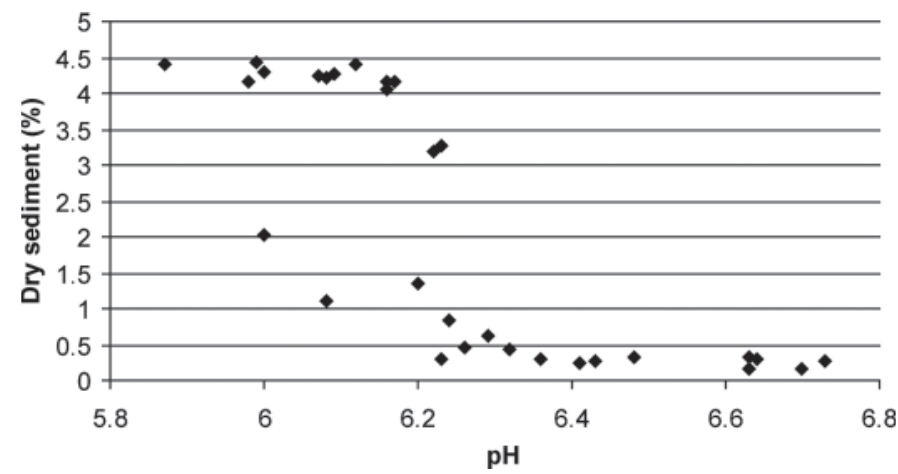

Figure 5. pH against dry sediment content (\%) in 9\% skim milk powder (SMP) with added calcium chloride heated at 60 to $80^{\circ} \mathrm{C}$.

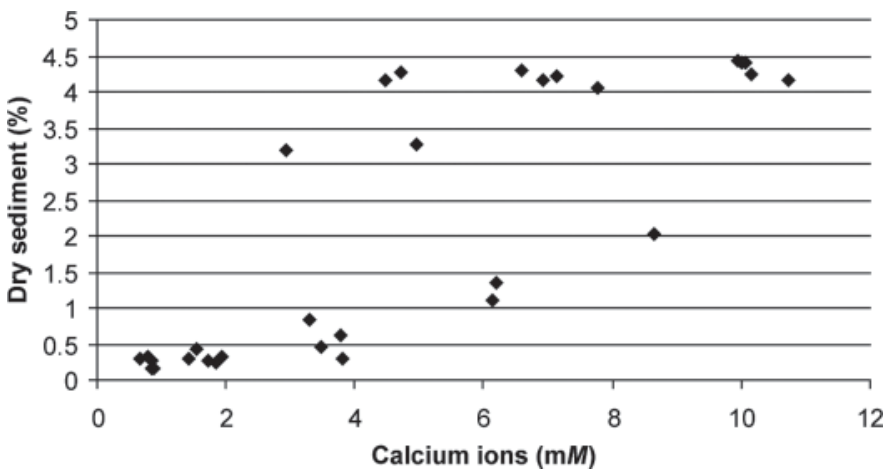

Figure 6. Calcium ion concentration $(\mathrm{m} M)$ against dry sediment content (\%) in 9\% skim milk powder (SMP) with added calcium chloride heated at 60 to $80^{\circ} \mathrm{C}$.

$\mathrm{pH}$ and $\mathrm{Ca}^{2+}$ change with temperature. Both $\mathrm{pH}$ and $\mathrm{Ca}^{2+}$ have been shown to decrease in milk as its temperature increases. The observation that $\mathrm{Ca}^{2+}$ decreases as temperature increases is interesting, because the resulting decrease in $\mathrm{pH}$ might be expected to increase $\mathrm{Ca}^{2+}$. However, the predominant effect is due to the decrease in calcium phosphate solubility, which results in a reduction in $\mathrm{Ca}^{2+}$. Even if dialysates removed at high temperature do show some temperature dependence, their "true" $\mathrm{pH}$ and $\mathrm{Ca}^{2+}$ at high temperature will be even lower than the values reported here. By how much this may differ is worthy of further investigation. In terms of better understanding of heat stability during commercial sterilization processes, the next stage is to understand the combined role of temperature and $\mathrm{pH}$ at high temperature. It is also important to understand what compositional factors affect how much $\mathrm{pH}$ and $\mathrm{Ca}^{2+}$ will change when milk is heated to high temperatures.

Omoarukhe et al. (2010) observed that milks with added calcium salts behave differently under in-container sterilization and UHT sterilization. Heat stabil-

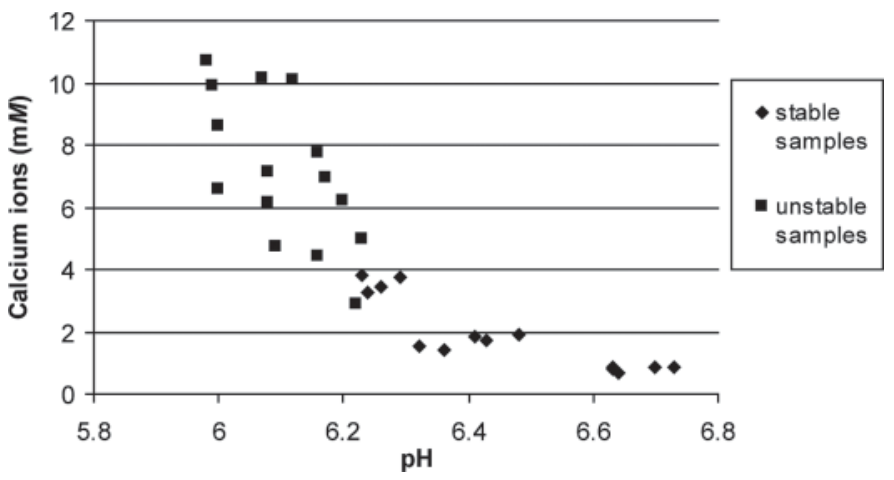

Figure 7. $\mathrm{pH}$ against calcium ion concentration $(\mathrm{m} M)$ in $9 \%$ skim milk powder (SMP) with added calcium chloride heated at 60 to $80^{\circ} \mathrm{C}$. 
ity is reduced by addition of $\mathrm{CaCl}_{2}$, but with increasing additions, this occurs at lower concentrations of calcium for UHT compared with in-container sterilization. Perhaps gelation is prevented and sediment formation is encouraged by flow-induced turbulence during UHT processing. This may also be different if the cans were agitated during the in-container sterilization procedure.

\section{CONCLUSIONS}

Adding $\mathrm{CaCl}_{2}$ to milk reduces the heat stability of milk. Poor heat stability was manifested in 2 ways: sediment formation followed by a firm coagulum. Production of sediment was observed at lower calcium additions, which changed to formation of a firmer gel-type structure at higher calcium additions. Dialysis provides a procedure for estimating $\mathrm{pH}$ and ionic calcium at high temperatures to allow a better understanding of their roles in heat stability.

\section{REFERENCES}

Boumpa, T., A. Tsioulpas, A. Grandison, and M. Lewis. 2008. Effects of phosphate and citrates on sediment formation in UHT goat's milk. J. Dairy Res. 75:160-166.

Chandrapala, J., I. McKinnon, M.-A. Augustin, and P. Udabage. 2010. The influence of milk composition on $\mathrm{pH}$ and calcium activity measured in situ during heat treatment of reconstituted skim milk. J. Dairy Res. 77:257-264.

Grandison, A. S. 1988. Effects of natural (or seasonal) variation in concentration of components of milk and addition of divalent cations on UHT processing characteristics. Int. J. Dairy Technol. 41:117-119.

Kaombe, D. D., Y. Du, and M. J. Lewis. 2012. Mineral partitioning in milk and milk permeates at high temperature. J. Dairy Res. $79: 1-6$.

Laemmli, U. K. 1970. Cleavage of structural protein during assembly of the head of bacteriophage T4. Nature 15:680-685.

Lewis, M. J., A. S. Grandison, M.-J. Lin, and A. Tsioulpas. 2011. Ionic calcium and $\mathrm{pH}$ as predictors of stability of milk to UHT processing. Milchwissenschaft 66:197-200.
Lin, M.-J., M. J. Lewis, and A. S. Grandison. 2006. Measurement of ionic calcium in milk. Int. J. Dairy Technol. 59:192-199.

Ma, Y., and D. M. Barbano. 2003. Milk pH as a function of $\mathrm{CO}_{2}$ concentration, temperature, and pressure in a heat exchanger. J. Dairy Sci. 86:3822-3830.

McKinnon, I. R., S. E. Yap, M. A. Augustin, and Y. Hemar. 2009. Diffusion-wave spectroscopy investigation of heated skim milks containing calcium chloride. Food Hydrocoll. 23:1127-1133.

Omoarukhe, E. D., N. On-Nom, A. S. Grandison, and M. J. Lewis, 2010. Effects of different calcium salts on properties of milk related to heat stability. Int. J. Dairy Technol. 63:504-511.

On-Nom, N., A. S. Grandison, and M. J. Lewis. 2010. Measurement of ionic calcium, $\mathrm{pH}$ and soluble divalent cations in milk at high temperature. J. Dairy Sci. 93:515-523.

Philippe, M., F. Gaucheron, and Y. Le Graet. 2004. Physicochemical characteristics of calcium supplemented skim milk: Comparison of three calcium salts. Neth. Milk Dairy J. 59:498-502.

Philippe, M., F. Gaucheron, Y. Le Graet, F. Michel, and A. Garem 2003. Physicochemical characterization of calcium supplemented skim milk. Lait 83:45-59.

Pouliot, Y., M. Boulet, and P. Paquin. 1989a. Observations on the heat induced salt balance changes in milk 1: Effect of heating time between 4 and $90^{\circ} \mathrm{C}$. J. Dairy Res. 56:185-192.

Pouliot, Y., M. Boulet, and P. Paquin. 1989b. An experimental technique for the study of milk salt balance. J. Dairy Sci. 72:36-40.

Pouliot, Y., M. Boulet, and P. Paquin. 1989c. Observations on the heat induced salt balance changes in milk. J. Dairy Res. 56:193-199.

Pyne, G. T. 1958. The heat coagulation of milk: II. Variations in sensitivity of casein to calcium ions. J. Dairy Res. 25:467-474.

Sievanen, K., T. Huppertz, A. L. Kelly, and P. F. Fox. 2008. Influence of added calcium chloride on the heat stability of unconcentrated and concentrated bovine milk. Int. J. Dairy Technol. 61:151-155.

Singh, G., S. Arora, G. S. Sharma, J. S. Sindhu, V. K. Kansal, and R. B. Sangwan. 2007. Heat stability and calcium bioavailability of calcium fortified milk. Lebenson. Wiss. Technol. 40:625-631.

Singh, H. 2004. Review of factors that affect $\mathrm{pH}$ dependence of the heat stability of milk. Int. J. Dairy Technol. 57:111-119.

Tsioulpas, A., A. Koliandris, A. S. Grandison, and M. J. Lewis. 2010. Effects of stabiliser addition and in-container sterilisation on selected properties of milk related to casein micelle stability. Food Chem. 122:1027-1034.

Walstra, P., and R. Jenness. 1984. Dairy Chemistry and Physics. John Wiley and Sons, New York, NY. 